Ann. Génét. Sél. anim., I975, 7 (3), 299-302.

\title{
HERITABILITY OF THE DIFFERENCES IN BODY WEIGHT BETWEEN SEXES AT DIFFERENT AGES IN TWO STRAINS OF CHICKENS
}

H. AYOUB and M. MAGRABY*

\author{
Faculty of Agriculture, \\ Ein Shams University \\ Cairo (Egypt) \\ * Animal Production Department, \\ Ministry of Agriculture, \\ Cairo (Egypt)
}

\section{SUMMARY}

The aim of this investigation was to study the genetic parameters of sexual dimorphism for body weight at 4,6 and 8 weeks of age for two strains : Dokki 4 and White Plymouth Rock.

The estimates of heritabilities of sex differences in body weight from sire component of variance at different ages ranged from -0.20 to 0.06 . These estimates suggest a very low magnitude of the inheritance of this trait and confirm that selection for sexual dimorphism through the sires is not expected to be effective.

\section{INTRODUCTION}

In advanced poultry industry, sexual-dimorphism received great attention during the last 8 years, since broiler production requires uniformity in body weight at market age. Regarding the fact, that males reach the suitable weight before females, due to sex-difference, a commonly occurring phenomenon in avian species, the degree of divergence between sexes has its economic importance.

The published heritability of the difference in weight between males and females ranged from - I.30 to 0.36 : BuvanENDRAN (I969), EisEN and LEGATES (I966), YoshidA and Collins (I967), Ayoub and Mérat (I972). The aim of this paper was to investigate the genetic parameters of sexual dimorphism for body weight at 4, 6 and 8 weeks of age for the strains, Dokki 4 and White Plymouth Rock. 


\section{MATERIAL, AND METHODS}

Two breeds of chickens were used. The first was Dokki 4, developed by back-crossing, Barred Plymouth Rock to Fayoumi for 4 generations and kept selfmaintained since I $95^{8}$ at Dokki experimental farm. The second was White Plymouth Rock which was imported from Holland about 20 years ago and was selfmaintained since at the same farm. 80 pullets from each breed were single sire mated in 8 groups, each of Io dams and I sire. 855 pedigreed chickens of the two breeds were obtained, of which 323 were Dokki 4 and 532 were Plymouth Rock. Chickens were weighed to the nearest gm at 4,6 and 8 weeks of age. Only dams having at least two progeny of each sex were used and equal numbers of progeny of each dam were recorded for analysis. Observation on each dam family was taken as the difference between the mean of the two sexes $\left(\bar{x}_{m}-\bar{x}_{f}\right)$. The form of the analysis of variance and expected mean squares (EMS) are the same as given by KINNEY and SHOFFner (1965) and as used in the paper by Ayoub and MERAT (1972). Heritability of the difference between sexes was calculated using the following formula.

$$
h_{(1-2)}^{2}=\frac{4 \sigma_{s}^{2}}{\sigma_{s}^{2}} \frac{\sigma_{d}^{2}+\sigma_{w}^{2}}{2}
$$

where $\sigma_{s}^{2}=$ variance due to differences between sires,

$\sigma_{a}^{2}=$ variance due to differences between dams,

$\sigma_{w}^{2}=$ variance due to differences between full-sibs.

Some explanation is due to illustrate the estimation of $h_{(1-2)}^{2}$, since there is no direct estimate for $\sigma_{w(1-2)}^{2}$ and $\sigma_{d(1-2)}^{2}$. EISEN and Legates (1966) ; BUVANENDRAN (1969), explained this point as follows :

$$
\sigma_{(1-2)}^{2}=\sigma_{1)}^{2}+\sigma_{(2)}^{2}-2 \operatorname{cov}_{(1 \cdot 2)} \text {. }
$$

Thus $\sigma_{t v}^{2}$ was obtained by substituting the values of $\sigma_{w}^{2}$ obtained for males and females in hierarchical analysis of variance on an individual basis (between and within full-sib families), according to KEMPTHORNe (1957). Assuming the expectation of $\operatorname{cov}_{(\mathbf{1 . 2})}$ as Zero $\sigma_{d}^{2}$ is then obtained by substitution.

\section{RESULTS AND DISCUSSION}

\section{Mean body weight}

The average weights and variances of males and females for the two breeds, given in table $I$, show that the difference between the two sexes increases with advancing age, and the variances from male data are greater than those from females in general. These results hold true with many available references.

\section{Heritability estimates of sex differences in body weight}

The results presented in table 2 give $h^{2}$ estimates ranging from -0.20 to 0.06 ; these estimates suggest a very low magnitude of the inheritance of this trait. The negative values of $h_{(1-2)}^{2}$ were found in 4 cases out of 6 . A similar negative estimate was obtained by Ayoub and MúraT (I972), at 8 weeks of age (-r.30), using the strain "Jouy ". They stated that this negative value was due to the sampling error generally associated with such estimates based on limited sire numbers, the estimates of negative values in this case corresponding to a very weak variation between sire families. 
TABLE I

Body weigts and variances

Poids du corps et variances

\begin{tabular}{|c|c|c|c|c|c|c|c|}
\hline \multirow{2}{*}{$\begin{array}{c}\text { Ag€ } \\
\text { in weeks }\end{array}$} & \multicolumn{3}{|c|}{ Females } & \multicolumn{3}{|c|}{ Males } & \multirow{2}{*}{$\begin{array}{c}\text { Difference } \\
\text { between } \\
\text { males and } \\
\text { females }(\mathrm{g})\end{array}$} \\
\hline & $n$ & (grams) & V & $n$ & $\begin{array}{c}\bar{x} \\
\text { (grams) }\end{array}$ & V & \\
\hline
\end{tabular}

1. Dokki Strain

\begin{tabular}{l|l|l}
4 & 168 & 17 \\
6 & 155 & 29 \\
8 & 155 & 37 \\
\hline & &
\end{tabular}

\begin{tabular}{l|l|l}
176 & 1226 & 155 \\
296 & 4288 & 157 \\
378 & 6635 & 134 \\
\hline
\end{tabular}

\begin{tabular}{|l|l|l}
192 & 1410 & 16 \\
312 & 4051 & 16 \\
408 & 8475 & 30 \\
\hline
\end{tabular}

\section{Plymouth Rock}

\begin{tabular}{|c|c|c|c|c|c|c|c|}
\hline 't & 301 & 171 & 1634 & 231 & 173 & 1140 & $\mathcal{2}$ \\
\hline f) & 301 & 297 & 3405 & 230 & 323 & 4179 & 25 \\
\hline 8 & 285 & 381 & 7846 & 225 & 429 & 8759 & 48 \\
\hline
\end{tabular}

TABLE 2

Variance camponents and heritabilities of sexual dimorphism for Dokki and White Plymouth Rock at different ages

Composants de la variance et héritabilités du dimorphisme sexuel pour Dokki et White Plymouth Rock à différents âges

\begin{tabular}{l|l|l|l} 
Age in \\
weeks
\end{tabular} \mid Source of variation $\mid$ d.f. $\left|\begin{array}{c}\text { Variance } \\
\text { component }\end{array}\right| h_{s}^{2}$

\section{Dokki Strain}

\begin{tabular}{|c|c|c|c|c|}
\hline $\begin{array}{l}\text { 4t weeks } \\
\text { of age }\end{array}$ & $\begin{array}{l}\text { Sire } \\
\text { Dam within Sire }\end{array}$ & $\begin{array}{r}7 \\
24\end{array}$ & $\begin{array}{r}0.32 \\
-3.54\end{array}$ & 0.06 \\
\hline $\begin{array}{l}6 \text { weeks } \\
\text { of age }\end{array}$ & $\begin{array}{l}\text { Sire } \\
\text { Dam within Sire }\end{array}$ & $\begin{array}{r}7 \\
23\end{array}$ & $\begin{array}{l}-3.44 \\
-2.47\end{array}$ & -0.20 \\
\hline $\begin{array}{l}8 \text { weeks } \\
\text { of age }\end{array}$ & $\begin{array}{l}\text { Sire } \\
\text { Dam within Sire }\end{array}$ & $\begin{array}{r}7 \\
23\end{array}$ & $\begin{array}{r}-3.99 \\
-20.14\end{array}$ & -0.12 \\
\hline \multicolumn{5}{|c|}{ 2. Plymouth Rock Strain } \\
\hline $\begin{array}{l}\text { ' weeks } \\
\text { of age }\end{array}$ & $\begin{array}{l}\text { Sire } \\
\text { Dam within Sire }\end{array}$ & $\begin{array}{r}7 \\
54 \\
54\end{array}$ & $\begin{array}{r}0.43 \\
-2.00\end{array}$ & -0.07 \\
\hline $\begin{array}{l}6 \text { weeks } \\
\text { of age }\end{array}$ & $\begin{array}{l}\text { Sire } \\
\text { Dam within Sire }\end{array}$ & $\begin{array}{r}7 \\
54\end{array}$ & $\begin{array}{l}0.05 \\
5.60\end{array}$ & +0.00 \\
\hline $\begin{array}{l}8 \text { weeks } \\
\text { of age }\end{array}$ & $\begin{array}{l}\text { Sire } \\
\text { Dam within Sire }\end{array}$ & $\begin{array}{r}7 \\
54\end{array}$ & $\begin{array}{r}-4.44 \\
16.31\end{array}$ & -0.11 \\
\hline
\end{tabular}


The estimates of $h^{2}$ of the body weight differences obtained from literature were generally low, e.g. EISEN and LEGATES (I966), working on Mice found estimates of $h_{(1-2)}^{2}$ as $0.010,0.084$ and 0.142 , for three, six and eight weeks weights respectively. Yoshida and Colinss (I967), reported a heritability estimate of 0.09 for sex differences in quails at 4 weeks of age ; they also stated that after their selection experiment, the sex difference in body weight in selected lines remained unchanged.

Findings from the present investigation confirm other findings in the literature, that selection for sexual dimorphism through the sires is not expected to be effective.

Ręu pour publication en septembre 1975.

\title{
ACKNOWLEDGEMENT
}

The authors wish to express their deep thanks and gratitude to Dr. M. KHIR EL Din, underSecretary of State-Ministry of Agriculture for his encouragement during the course of this work. Thanks are also due to Dr. A. Mostageer, Faculty of Agriculture Cairo University and Dr. S. Galal, Faculty of Agriculture Ein Shams University for their advice and useful criticism.

\author{
RÉSUMÉ \\ HÉRITABILITÉ DES DIFFÉRENCES DU POIDS CORPOREI, ENTRE SEXES \\ A DIFFÉRENTS AGES DANS DEUX SOUCHES DE VOLAILLES
}

Le but de cette recherche était d'étudier les paramètres génétiques du dimorphisme sexuel du poids corporel à 4,6 et 8 semaines d'âge pour les deux souches : Dokki 4 et Pklymouth Rock blanche.

Les estimations d'héritabilité des différences entre sexes pour le poids corporel basées sur la composante " père " de la variance aux différents âges allaient de $-0,20$ à 0,06 . Ces estimations suggèrent un très faible ordre de grandeur de l'héritabilité de ce caractère et laissent prévoir un manque d'efficacité de la sélection pour le dimorphisme sexuel basée sur le père.

\section{REFERENCES}

Ayoub H., Mérat P., I972. Différences entre familles pour le dimorphisme sexuel du poids à un âge donné chez la Poule. Ann. Génét. Sél. anim., 4, 45-59.

Buvanendran V., I969. The heritability and genetic correlations of sexual dimorphism for ro week weight in poultry. Br. Poult. Sci., 10, 32r-325.

EISEN E. J., LegatTes J. E., I966. Genotype, Sex, interaction and the genetic correlation between the sexes for body weight in Mus Musculus. Genetics, 54, 611-623.

Kempthorne O., 1957. An introduction to genetic statistics. John Willey and Sons, Inc., New York. Kinney T.B. J., Shoffner R. N., 1965. Heritability estimates and genetic correlations among several traits in a meat type poultry population. Poult. Sci., 44, I020-1032.

Yoshida S., Collins W. M., r967. Individual Selection for 4 weeks body weight in Japanese quail in relation to sex dimorphism. Poult. Sci., 46, r34I (abstr.). 